\title{
Level of contamination with deoxynivalenol, zearalenone and fumonisins in cereal products - assessment of consumer exposure
}

\author{
Piotr Pokrzywa ${ }^{1, A-D \oplus}$, Magdalena Surma ${ }^{2, A, E-F \oplus}$ \\ ${ }^{1}$ Regional Sanitary-Epidemiological Station, Kraków, Poland \\ ${ }^{2}$ Faculty of Food Technology, Małopolska Centre for Food Monitoring, University of Agriculture, Kraków, Poland \\ A - Research concept and design, B - Collection and/or assembly of data, C - Data analysis and interpretation, \\ $D$ - Writing the article, E-Critical revision of the article, F- Final approval of the article
}

Pokrzywa P, Surma M. Level of contamination with deoxynivalenol, zearalenone and fumonisins in cereal products - assessment of consumer exposure. Ann Agric Environ Med. 2022; 29(1): 72-79. doi: 10.26444/aaem/144416

\begin{abstract}
Objective. The main aim of this study was to determine the content of mycotoxins, such as: deoxynivalenol (DON), zearalenone (ZEA) and fumonisins (FUM) in cereal products, and such products intended for infants. The secondary objective was to assess consumer exposure to the DON, ZEA and FUM occurring in cereal products, including those intended for infants and young children.

Materials and method. The study included cereals and cereal products such as flours, grits, pastas, products of the bakery industry, snacks and cereal products intended for infants and young children, available in retail outlets in the Małopolska Province of Poland. DON content was determined by high-performance liquid chromatography with a DAD detector, while the contents of ZEA and FUM were detected by high-performance liquid chromatography with fluorescence detection.

Results. The determined concentration of mycotoxins exceeded the maximum level specified in food law in only two cases. DON level in maize flour was $1511.0 \mu \mathrm{g} \mathrm{kg}^{-1}$ and exceeded the maximal residue level (MRL) set at $750.0 \mu \mathrm{g} \mathrm{kg}^{-1}$. The value of MRL for ZEA was over the permissible value of $75.0 \mu \mathrm{g} \mathrm{kg}^{-1}$ in the maize flour sample only, and was $212.0 \mu \mathrm{g} \mathrm{kg}{ }^{-1}$. None of the samples examined was beyond the permissible level of FUM.

Conclusions. Levels higher than those permissible for the examined cereal products were noted in only two cases. FUMs were the most commonly found Fusarium mycotoxins, followed by DON and ZEA. The mean exposure doses of the assessed mycotoxins, resulting from the consumption of cereal products in the selected populations, were at low levels (reaching a maximum of $6.81 \%$ ) and did not exceed the tolerable daily intake (TDI) or provisional maximum tolerable daily intake (PMTDI). Therefore, the observed average chronic exposure dose not pose a health risk to consumers.
\end{abstract}

\section{Key words}

zearalenone, mycotoxins, cereal products, deoxynivalenol, fumonisins (sum of $B_{1}$ and $B_{2}$ ), cereal products for infants and young children

\section{INTRODUCTION}

Food contamination with natural toxins, particularly mycotoxins, is an obvious and serious problem for agriculture and the food industry worldwide [1]. In recent years, significant advances in food toxicology along with the development of analytical techniques have drawn attention to mycotoxins produced by Fusarium species, widespread in temperate climate zones, including Europe [2]. They are a large group of compounds with diverse chemical structures and a broad spectrum of toxic effects. The main Fusarium mycotoxins which can be found on cereal grains and cereal products, are DON, ZEA and FUM. Their biosynthesis can be affected by many factors, including not only temperature, but also humidity, oxygen level, mechanical crop damage and the presence of mould spores $[3,4,5]$. DON, belonging to the type B trichothecenes, is mainly produced by Fusarium graminearum and F. culmorum on cereals (wheat, maize, barley and oats) [6]. This toxin, very stable during both storage

Address for correspondence: Piotr Pokrzywa, Regional Sanitary-Epidemiological Station in Department of Food Hygiene, Nutrition and Teaching Processes, Krakow Poland

E-mail: p.pokrzywa@wsse.krakow.pl

Received: 01.08.2021; accepted: 01.12.2021; first published: 19.12.2021 and pre-treatment or processing and the hydrothermal treatment of food, is undegradable at high temperatures [7]. The FUM group of toxic metabolites is produced mainly by Fusarium verticillioides and F. proliferatum, which most frequently attack maize crops worldwide. When considering FUM toxicity, the most toxic are $\mathrm{B}_{1}\left(\mathrm{FB}_{1}\right), \mathrm{B}_{2}\left(\mathrm{FB}_{2}\right)$ and $\mathrm{B}_{3}\left(\mathrm{FB}_{3}\right)$ [8]. $\mathrm{FB}_{1}$ is classified by the International Agency for Research on Cancer (IARC) as a Group $2 b$ potential human carcinogen. Furthermore, FUM are neurotoxins due to the fact that they can damage the biosynthesis pathway of sphingosine, which is a component of the brain and nervous system [9]. In turn, ZEA is produced by F. graminearum, F. culmorum and $F$. equiseti, the species most commonly attacking maize and wheat crops. The ZEA belongs to the xenoestrogens, has a similar chemical structure to natural estrogen, such as $17 \beta$-estradiol, and therefore can bind to estrogen receptors, thus disrupting the hormonal balance and leading to numerous diseases of the reproductive tract [10].

In order to reduce the exposure to potential contamination, European Commission Regulation (EC) No. 1881/2006 of the European Parliament and of the Council of 19 December 2006, set limits for the presence of these mycotoxins in food, as well as maximum levels for certain contaminants in foodstuffs [11]. The established permissible levels in 
foodstuffs were: for DON, between $200 \mu \mathrm{g} \mathrm{kg}$ (food for infants and young children) and $1,750 \mu \mathrm{g} \mathrm{kg}^{-1}$ (unprocessed maize); for ZEA, between $20 \mu \mathrm{g} \mathrm{kg}^{-1}$ (food for infants and young children) and $400 \mu \mathrm{g} \mathrm{kg}^{-1}$ (refined maize oil); and for FUM, between $200 \mu \mathrm{g} \mathrm{kg}^{-1}$ (food for and infants and young children and 4,000 $\mu \mathrm{g} \mathrm{kg}^{-1}$ (unprocessed maize). The Joint FAO/WHO Expert Committee on Food Additives (JECFA) set a provisional maximum tolerable daily intake (PMTDI) of $1.0 \mu \mathrm{g} \mathrm{kg}^{-1}$ body weight (b.w.) per day for DON, and a PMTDI of $2.0 \mu \mathrm{g} \mathrm{kg}^{-1}$ b. w. per day for $\mathrm{FB}_{1}, \mathrm{FB}_{2}$, and $\mathrm{FB}_{3}$, occurring alone or in combination. The TDI for ZEA was set at $0.25 \mu \mathrm{g} \mathrm{kg}^{-1} \mathrm{~b}$. w. per day [12]. There are no current literature data on the presence of these toxins in cereal products and in such products intended for infants and young children, available in retail in Poland.

\section{OBJECTIVE}

The main aim of this study was to determine the level of selected Fusarium mycotoxins, i.e. DON, ZEA and FUM (expressed as the sum of $\mathrm{FB}_{1}$ and $\mathrm{FB}_{2}$ ) in various types of cereal products. The second aim was to assess consumer exposure risk resulting from the intake of DON, ZEA and FUM from cereal products and these products intended for infants and young children.

\section{MATERIALS AND METHOD}

The experimental material consisted of cereals and cereal products, including flours, grits, pastas, products of the bakery industry, snacks and cereal products intended for infants and young children, available in retail out; lets in the Małopolska Province of Poland in 2016-2020. A total of 831 samples were examined in triplicate, which produced 2,493 analytical results. In 2016, 182 samples were examined, including: 83 for DON, 75 for ZEA, and 24 for FUM. In the subsequent years, these values were, respectively: 192 (DON - 86, ZEA - 82, and FUM - 24); 142 (DON - 75, ZEA - 48, and FUM - 19); 187 (DON - 82, ZEA - 82, and FUM - 23); and $128(\mathrm{DON}-68, \mathrm{ZEA}-45$, and FUM - 15). The samples, collected by inspectors of sanitary and epidemiological stations in the Małopolska Province according to the principles defined in European Commission Regulation (EC) 401/2006 [13], were examined for contamination levels of DON, ZEA and FUM. The DON content was determined by high-performance liquid chromatography with a DAD detector (HPLC-DAD), while the contents of ZEA and FUM were detected by high-performance liquid chromatography with fluorescence detection (HPLC-FLD). Table 1 presents the parameters of the analysis for the examined groups of food products, corresponding to the specific method.

\section{DETERMINATION OF DON CONTENT}

\section{Sample preparation procedure}

Cereal products for adults, infants and young children. $25 \mathrm{~g}$ of a homogeneous sample, $8 \mathrm{~g}$ of polyethylene glycol and $200 \mathrm{ml}$ of deionized water, were mixed at high speed for about 2 min using a laboratory mixer. The extract was filtered through a filter paper and the filtrate collected in
Table 1. Performance parameters according to mycotoxins and food products

\begin{tabular}{|c|c|c|c|c|c|}
\hline Toxins & Food products & Method & $\begin{array}{c}\text { LOD } \\
(\mu \mathrm{g} / \mathrm{kg})\end{array}$ & $\begin{array}{c}\text { LOQ } \\
(\mu \mathrm{g} / \mathrm{kg})\end{array}$ & $\begin{array}{c}\text { Recovery } \\
\text { (\%) }\end{array}$ \\
\hline \multirow{2}{*}{$\begin{array}{l}\text { Deoxy- } \\
\text { nivalenol }\end{array}$} & $\begin{array}{l}\text { Cereal-based food } \\
\text { products }\end{array}$ & \multirow{2}{*}{$\begin{array}{l}\text { HPLC- } \\
\text { DAD }\end{array}$} & 50 & 100 & 89 \\
\hline & $\begin{array}{l}\text { Cereal-based food for } \\
\text { infants and young children }\end{array}$ & & 20 & 40 & 80 \\
\hline \multirow{2}{*}{$\begin{array}{l}\text { Fumo- } \\
\text { nisins }\end{array}$} & $\begin{array}{l}\text { Cereal-based } \\
\text { food products }\end{array}$ & \multirow{2}{*}{ HPLC-FL } & 75 & 150 & 88 \\
\hline & $\begin{array}{l}\text { Cereal-based food for } \\
\text { infants and young children }\end{array}$ & & 75 & 150 & 88 \\
\hline \multirow{2}{*}{$\begin{array}{l}\text { Zearale- } \\
\text { none }\end{array}$} & $\begin{array}{l}\text { Cereal-based } \\
\text { food products }\end{array}$ & \multirow{2}{*}{ HPLC-FL } & 4.5 & 15 & 97 \\
\hline & $\begin{array}{l}\text { Cereal-based food for } \\
\text { infants and young children }\end{array}$ & & 4.5 & 15 & 97 \\
\hline
\end{tabular}

an Erlenmeyer flask. Afterwards, 8 and $20 \mathrm{ml}$ of filtrate for cereal products for adults (CPA).

Cereal products for adults, infants and young children (CPI). The cereal products were taken and passed through a DONprep affinity column at a rate of approx 1 drop per second or by gravity. The column was then washed with $20 \mathrm{ml}$ of phosphate buffer in PBS saline for CPA and 10 $\mathrm{ml}$ of PBS for CPI, and air dried for approx. $15 \mathrm{sec}$. under reduced pressure.

The DON was eluted into a vial by passing 6 and $1.5 \mathrm{ml}$ of methanol through the column at a rate of approx. 1 drop per second for CPA and CPI, resectivelly. The residue was removed by passing air through the column, and the eluate evaporated to dryness under a stream of nitrogen at $60^{\circ} \mathrm{C}$. The residue was dissolved with $15 \%$ methanol solution to a volume of $1 \mathrm{ml}$. The eluate thus obtained was subjected to chromatographic analysis.

Apparatus. DON quantification was carried out using a Varian liquid chromatograph (model ProStar 335), equipped with a DAD detector. Analysis conditions: mobile phase methanol: water $(15: 85, \mathrm{v} / \mathrm{v})$; column operating temperature: $25^{\circ} \mathrm{C}$; flow rate: $1 \mathrm{ml} \mathrm{min}^{-1}$; injection volume: $100 \mu \mathrm{l}$, detector wavelength $\lambda=220 \mathrm{~nm}$. Separations were carried out on a Gemini NX 5u C18 110A column $(250 \times 4.6 \mathrm{~mm} ; 4 \mu \mathrm{m})$. The detector collected a spectrum from $220 \mathrm{~nm}$ to $310 \mathrm{~nm}$ and monitors at $220 \mathrm{~nm}$.

Calibration solutions were prepared from the DON stock standard solution in $2 \mathrm{ml}$ flasks by replenishing the flasks with $9.5 \%$ methanol solution. The DON concentrations of the solutions were, respectively: $0.1 ; 0.2 ; 0.5 ; 0.75 ; 1$, and $2.0 \mu \mathrm{g} \mathrm{ml}^{-1}$.

\section{DETERMINATION OF ZEA CONTENT}

Sample preparation procedure. $25 \mathrm{~g}$ of homogeneous sample and $125 \mathrm{ml}$ of acetonitrile: water $(75: 25, \mathrm{v} / \mathrm{v})$ mixture were mixed at high speed for approx. $2 \mathrm{~min}$ in a homogenizer. The extract was filtered through a filter paper and the filtrate obtained was collected in an Erlenmeyer flask. Then, $20 \mathrm{ml}$ of filtrate was taken, to which $80 \mathrm{ml}$ of PBS was added and the $\mathrm{pH}$ adjusted to 7.4 (with $0.1 \mathrm{M} \mathrm{NaOH}$ solution), prior to purification on the column. Afterwards, $25 \mathrm{ml}$ of the diluted 
and mixed extract was passed through an EASI-EXTRACT ${ }^{\circledast}$ ZEARALENONE immune affinity column at approximately $5 \mathrm{ml} \mathrm{min}^{-1}$. The column was then washed with $20 \mathrm{ml}$ of PBS (at a rate of approx $5 \mathrm{ml} \mathrm{min}^{-1}$ ) and dried by applying a slight vacuum for approx. $15 \mathrm{sec}$.

ZEA was eluted into a vial by passing $1.5 \mathrm{ml}$ of $100 \%$ acetonitrile through the column. The column was then washed with $1.5 \mathrm{ml}$ of water for HPLC. The eluate collected ( $3 \mathrm{ml}$ ) by the method was subjected to chromatographic analysis (HPLC-DAD).

Apparatus. The ZEA quantification was performed using a SHIMADZU RF 20Axs liquid chromatograph with a FLD fluorescence detector. The following analytical conditions were applied: mobile phase composition: methanol:water $(80: 20, \mathrm{v} / \mathrm{v})$ solution, column operating temperature $-35^{\circ} \mathrm{C}$, flow rate $-\mathrm{ml} \mathrm{min}^{-1}$, injection volume $-20 \mu \mathrm{l}$, excitation wavelength $\lambda=274 \mathrm{~nm}$, emission wavelength $\lambda=455 \mathrm{~nm}$. The analytical column C18 Nucleosil 100-3 Protect I $(150 \mathrm{~mm} \times 4.6 \mathrm{~mm})$ and variable length fluorescence detector were used.

From the ZEA stock standard solution, calibration solutions were prepared by filling flasks $(10 \mathrm{ml})$ with methanol-water solution. The ZEA concentrations in these solutions were as follows: 5, 10, 20, 40, 80, 120 and $200 \mathrm{ng} \mathrm{ml}^{-1}$.

\section{DETERMINATION OF FUM CONTENT}

Sample preparation procedure. $25 \mathrm{~g}$ of a well-ground homogeneous sample was mixed with $100 \mathrm{ml}$ of the acetonitrile:methanol:water (25:25:50, v/v/v) mixture. Then, $2.5 \mathrm{~g}$ of sodium chloride was added and the whole stirred at high speed in a homogenizer for approx. $2 \mathrm{~min}$. The extract was filtered through a filter paper into an Erlenmayer flask. Afterwards, $10 \mathrm{ml}$ of the filtrate was taken, diluted with $40 \mathrm{ml}$ of PBS (pH 7.4), mixed and filtered through a glass fibre filter. Using an adapter and syringe, $20 \mathrm{ml}$ of the diluted extract (equivalent to $1.0 \mathrm{~g}$ of the sample) was passed through a Fumoniprep affinity column (placed in the SPE kit) at a rate of approx. $5 \mathrm{ml} \mathrm{min}^{-1}$. The column was washed with $10 \mathrm{ml}$ of PBS at a rate of approx. $5 \mathrm{ml} \mathrm{min}^{-1}$ and then dried under slight vacuum for about $15 \mathrm{sec}$. FUM were eluted into a vial by passing $1.5 \mathrm{ml}$ of $100 \%$ methanol through the column. During methanol passage through the column, back-suction was applied 3 times to completely denature antibodies. The residue was removed by passing air through the column, and the column flushed with $1.5 \mathrm{ml}$ of water for HPLC. The collected eluate in a volume of $3 \mathrm{ml}$ was ready for HPLC determination.

Apparatus. Quantitative analysis of FUM was performed using a SHIMADZU RF 20Axs liquid chromatograph with the FLD fluorescence detector. The conditions applied were: mobile phase - methanol:phosphate buffer; column operating temperature $-35^{\circ} \mathrm{C}$, flow rate $-0.9 \mathrm{ml} \mathrm{min}^{-1}$, injection volume - $20 \mu \mathrm{l}$, excitation wavelength $\lambda=335 \mathrm{~nm}$, and emission wavelength $\lambda=440 \mathrm{~nm}$. Analysis was conducted on a C18 Kinetex $2.6 \mu \mathrm{m}, 100 \mathrm{~mm} \times 4.6 \mathrm{~mm}$ analytical column. From the stock standard solution of fumonisin $B_{1}$ and $B_{2}$, calibration solutions were prepared by filling the flasks $(2 \mathrm{ml})$ with acetonitrile-water mixture. The FUM concentrations of the solutions were respectively: 50, 100, 200, 400, 500 and $1000 \mathrm{ng} \mathrm{ml}^{-1}$.
Chemicals. Methanol, polyethylene glycol, acetonitrile, phosphate buffer, $0.1 \mathrm{M}$ sodium hydroxide solution, phthalaldehyde, thiofluor, 5\% o-phosphoric acid, $0.1 \mathrm{M}$ borax solution, and $0.1 \mathrm{M}$ sodium dihydrogen phosphate solution, were purchased from Sigma-Aldrich (Poznań, Poland). Ochraprep ${ }^{\circledast}$ immunoaffinity columns (IAC) were provided by 'FABIMEX' Więcek Sp. j. Phosphate buffer in saline (PBS) was prepared as follows: $8.0 \mathrm{~g} \mathrm{NaCl}, 1.2 \mathrm{~g}$ sodium hydrogen phosphate, $0.2 \mathrm{~g}$ potassium dihydrogen phosphate, and $0.2 \mathrm{~g} \mathrm{KCl}$ were dissolved in $990 \mathrm{ml}$ of water. The $\mathrm{pH}$ was then adjusted to 7.4 with $0.1 \mathrm{M}$ sodium hydroxide solution, and the whole was made up to $1,000 \mathrm{ml}$ with water.

Preparation of the mobile phase: developing phase - $154 \mathrm{ml}$ of methanol, $46 \mathrm{ml}$ of sodium dihydrogen phosphate, and $16.8 \mathrm{ml}$ of o-phosphoric acid were poured into a flask, mixed, filtered, and degassed using an ultrasonic scrubber. In the pre-column derivatization phase, $80 \mathrm{mg}$ of phthalaldehyde was dissolved in $2 \mathrm{ml}$ of methanol after which $200 \mathrm{mg}$ of thiofluor was dissolved in $2 \mathrm{ml}$ of borax. The vessel used for thiofluor dissolvation was then rinsed with $2 \mathrm{ml}$ of borax and $6 \mathrm{ml}$ of borax added.

Dietary exposure assessment. Consumer exposure assessment resulting from the consumption of cereal products was estimated with regard to the PMTDI (for DON and FUM) and the TDI (for ZEA). The results were expressed as \%PMTDI or \%TDI. The exposure dose was calculated according to the following formula:

$\left(\mu \mathrm{gg}^{-1}\right.$ body weight per day) $=$ mycotoxin level $\left(\mu \mathrm{g} \mathrm{kg}{ }^{-1}\right) \times$ average food intake (kg per person per day) $\times$ average body weight $^{-1}\left(\mathrm{~kg}^{-1}\right.$ body weight per person).

The maximum contamination values determined for individual mycotoxins, as well as the lower bound (LB) and upper bound (UB) values were used for calculations. These values are applied when the percentage of results below the Limit of Detection (LOD) or Limit of Quantitation (LOQ) is higher than 50\%. According to the European Food Safety Authority (EFSA) [14] guidance: at the lower-bound (LB), results below the LOD were replaced by zero and those below the LOQ by the LOD; at the upper-bound (UB) the results below the LOD were replaced by the value of the LOD and those below the LOQ were replaced by the value reported as LOQ.

The middle bound (MB) value was calculated as the difference between UB and LB.

For DON calculations, in wheat flour, the reference product was bread baked from this flour, i.e. mixed bread with $40 \%$ proportion of wheat flour. Based on the study by Vidal et al. [15], it was also assumed that the DON content in flour is reduced by $26 \%$ during baking. Calculations were based on the average body weight values given for 7 age groups (coded A - G), according to the division set by the Nutritional Standards for the Polish population [16]. These groups included: children aged 4-6, body weight - $19 \mathrm{~kg}$ (A); children aged 7-9, body weight - $27 \mathrm{~kg}(\mathrm{~B})$; boys and girls aged $10-12$, body weight $-38 \mathrm{~kg}(\mathrm{C})$; boys and girls aged 13-15, body weight $-52.5 \mathrm{~kg}(\mathrm{D})$; boys and girls aged 16-18, body weight $-61.5 \mathrm{~kg}(\mathrm{E})$; men from 19 years, body weight $-70 \mathrm{~kg}$ (F); and women from 19 years, body weight - $60 \mathrm{~kg}(\mathrm{G})$.

When establishing the average intake of cereal products, the EFSA Comprehensive European Food Consumption 
Database was used. However, as there is no data in this database on an average intake of cereal products in Poland, this value has been determined on the basis of own survey conducted among 152 people. The questionnaire, which asked for gender and age, also included questions about the consumption of specific cereal products.

Statistical analysis. Results were analysed using two-way analysis of variance (ANOVA) at a significance level of $p<0.05$. Statistical analysis was performed using Statistica Ver. 10.0 software. The relationship between the type of mycotoxin and the type of product was investigated. The analysis concerned products in which all 3 toxins were determined. These were: breakfast cereals, maize flour and cereal products intended for infants and young children.

\section{RESULTS AND DISCUSSION}

A total of 831 samples were analysed: 394 for DON, 332 for ZEA and 105 for FUM. The percentage of positive samples was $10.2 \%, 2.1 \%$ and $13.3 \%$, respectively. The mean DON values for individual products ranged from $114.6 \mu \mathrm{g} \mathrm{kg}$ ${ }^{1}-463.9 \mu \mathrm{g} \mathrm{kg}^{-1}$ (Tab. 2). Of the examined assortment of cereal products, this toxin was most often found in maize flour (33.3\%), pasta (31.0\%), bread and bakery products $(25.0 \%)$ and in wheat flour (12.0\%).

In only one case, maize flour, the DON content exceeded the maximum level specified in the regulations $-511 \mu \mathrm{g} \mathrm{kg}^{-1}$. This toxin was not found in cereal products or bran samples intended for infants and young children.

Studies by Dobosz et al. [17] on the level of the DON, ZEA and FUM in flours available in retail in the Silesian Province in Poland, showed lower DON contaminations of wheat flour, ranging from $73-472 \mu \mathrm{g} \mathrm{kg}^{-1}$, mean value $-31 \mu \mathrm{g} \mathrm{kg}^{-1}$. The contamination of maize flour ranged from $85-876 \mu \mathrm{g} \mathrm{kg}^{-1}$, mean value $-335 \mu \mathrm{g} \mathrm{kg}^{-1}$. Higher DON contamination levels were reported by Mruczyk et al. [18] in flour from western Poland. The values ranged from $146-646 \mu \mathrm{g} \mathrm{kg}^{-1}$, averaging $336.3 \mu \mathrm{g} \mathrm{kg}^{-1}$. On the other hand, even higher contamination with this toxin were determined by Darsanaki et al. [19] in flour originating from Iran, where DON was detected at the average level of $630.5 \mu \mathrm{g} \mathrm{kg}^{-1}$ in 80 of 96 wheat flour samples (83.3\%), in which its content ranged from $23-1270 \mu \mathrm{g} \mathrm{kg}^{-1}$.

Higher levels and greater percentages of positive samples have also been noted in many studies conducted in the European Union. In the Czech Republic, DON was found in 16 out of 17 (94\%) wheat bread samples examined by Malachova et al. [20], ranging from $13-350 \mu \mathrm{g} \mathrm{kg}^{-1}$. In turn, in Spain, this toxin was found in 21 of $75(28 \%)$ samples at levels ranging from $12.2-147 \mu \mathrm{g} \mathrm{kg}^{-1}$, as reported GonzálezOsnaya et al. [21]. The authors determined this toxin in 47 of $75(62.7 \%)$ pasta samples, but in higher amounts, ranging from 10.9-623 $\mu \mathrm{g} \mathrm{kg}^{-1}$ However, a study by Golge \& Kabak [22] on the prevalence of DON and ZEA in cereals and cereal products in Turkey, proved a mean DON content in pasta amounting to $49.3 \mu \mathrm{g} \mathrm{kg}^{-1}$

The least frequently detected toxin was ZEA, which was found in only 7 of 332 samples examined (2.1\%) (Tab. 3). Of the cereal products investigated, this toxin was most often found in maize flour (10\%), were its maximum permissible level was exceeded. The mean ZEA contents in various cereal products ranged from $17.1 \mu \mathrm{g} \mathrm{kg}^{-1}-148.2 \mu \mathrm{g} \mathrm{kg}^{-1}$. This toxin was not found in such products as rye flour, bran, pasta, nor in cereal products intended for infants and young children. Sirot et al. [23], who studied consumer exposure to mycotoxins in France, determined lower ZEA contents in the examined products. Contamination levels in bread ranged from 1.5$5 \mu \mathrm{g} \mathrm{kg}^{-1}$, and in pasta from 1.1-4.1 $\mathrm{g} \mathrm{kg}^{-1}$. In turn, CanoSancho et al. [24] in their studies on the presence of ZEA in food in Spain, found lower ZEA mean values in maize snacks $\left(5.9 \mu \mathrm{g} \mathrm{kg}^{-1}\right)$, sliced bread $\left(3.7 \mu \mathrm{g} \mathrm{kg}^{-1}\right)$ and pasta $\left(3.8 \mu \mathrm{g} \mathrm{kg}^{-1}\right)$.

Table 3. The content of ZEA in analyzed samples

\begin{tabular}{|c|c|c|c|c|c|c|}
\hline Product & $\begin{array}{l}\text { No. positive samples/ } \\
\text { examined samples (\%) }\end{array}$ & $\begin{array}{c}\text { Range } \\
\left(\min -\max , \mu g \mathrm{~kg}^{-1}\right)\end{array}$ & $\begin{array}{l}\text { Mean of positive } \\
\text { samples }\left(\mu \mathrm{g} \mathrm{kg}{ }^{-1}\right)\end{array}$ & $\begin{array}{c}\text { Mean MB } \\
\left.(\mathrm{UB}-\mathrm{LB}, \mu \mathrm{g} \mathrm{kg})^{-1}\right)\end{array}$ & UE ML $\left(\mu \mathrm{g} \mathrm{kg}^{-1}\right)$ & $\begin{array}{c}\text { The number of } \\
\text { samples above MRL }\end{array}$ \\
\hline Wheat flour & $\begin{array}{c}1 / 50 \\
(2)\end{array}$ & 29.4 & 29.4 & $\begin{array}{c}4.6 \\
(5.2-0.6)\end{array}$ & 75 & 0 \\
\hline Rye flour & $0 / 18$ & - & - & $\begin{array}{c}4.5 \\
(4.5-0)\end{array}$ & 75 & 0 \\
\hline Maize flour & $\begin{array}{l}2 / 20 \\
(10)\end{array}$ & $84.4-212$ & 148.2 & $\begin{array}{c}4.1 \\
(18.9-14.8) \\
\end{array}$ & 75 & 1 \\
\hline Bran & $0 / 15$ & - & - & $\begin{array}{c}5.2 \\
(5.2-0)\end{array}$ & 75 & 0 \\
\hline Grits & $\begin{array}{l}1 / 30 \\
(3.3)\end{array}$ & 27.3 & 27.3 & $\begin{array}{c}4.4 \\
(5.3-0.9)\end{array}$ & 75 & 0 \\
\hline Pasta & $0 / 25$ & - & - & $\begin{array}{c}4.5 \\
(4.5-0)\end{array}$ & 20 & 0 \\
\hline Cereal snacks & $\begin{array}{c}1 / 25 \\
(4)\end{array}$ & 17.1 & 17.1 & $\begin{array}{c}4 \\
(5-1)\end{array}$ & 100 & 0 \\
\hline Breakfast cornflakes & $\begin{array}{l}1 / 37 \\
(2.7)\end{array}$ & 21.7 & 21.7 & $\begin{array}{c}4.4 \\
(5-0.6)\end{array}$ & 100 & 0 \\
\hline $\begin{array}{l}\text { Cereal products for infants and } \\
\text { young children }\end{array}$ & $0 / 90$ & - & - & $\begin{array}{c}4.5 \\
(4.5-0)\end{array}$ & 20 & 0 \\
\hline
\end{tabular}

MB (UB-LB): middle bound (upper bound- lower bound). UB - results below LOD were replaced by LOD and results below LOQ by LOQ. LB - results below LOD were replaced by 0 and results below LOQ by LOD. 
Table 2. The content of DON in analyzed samples

\begin{tabular}{|c|c|c|c|c|c|c|}
\hline Product & $\begin{array}{l}\text { No. positive samples/ } \\
\text { examined samples (\%) }\end{array}$ & $\begin{array}{c}\text { Range } \\
\left(\min -\max , \mu g k^{-1}\right)\end{array}$ & $\begin{array}{l}\text { Mean of positive } \\
\text { samples }\left(\mu \mathrm{g} \mathrm{kg}^{-1}\right)\end{array}$ & $\begin{array}{c}\text { Mean MB } \\
(\mathrm{UB}-\mathrm{LB}, \mu \mathrm{g} \mathrm{kg})\end{array}$ & UE ML ( $\left.\mu \mathrm{g} \mathrm{kg}^{-1}\right)$ & $\begin{array}{c}\text { The number of } \\
\text { samples above MRL }\end{array}$ \\
\hline Wheat flour & $\begin{array}{l}9 / 75 \\
(12)\end{array}$ & $110.6-607$ & 345.4 & $\begin{array}{c}45.8 \\
(87.3-41.4)\end{array}$ & 750 & 0 \\
\hline Rye flour & $\begin{array}{l}2 / 32 \\
(6.3) \\
\end{array}$ & $138-227$ & 182.5 & $\begin{array}{c}46.9 \\
(58.3-11.4)\end{array}$ & 750 & 0 \\
\hline Maize flour & $\begin{array}{c}8 / 24 \\
(33.3)\end{array}$ & $129-1511$ & 463.9 & $\begin{array}{c}33.3 \\
(188-154.6)\end{array}$ & 750 & 1 \\
\hline Bran & $0 / 17$ & - & - & $\begin{array}{c}50 \\
(50-0\end{array}$ & 750 & 0 \\
\hline Grits & $\begin{array}{l}1 / 32 \\
(3.1)\end{array}$ & 122 & 122 & $\begin{array}{c}50 \\
(53.8-3.8)\end{array}$ & 750 & 0 \\
\hline Pasta & $\begin{array}{l}9 / 29 \\
(31)\end{array}$ & $105.6-297$ & 168.8 & $\begin{array}{c}34.5 \\
(86.9-34.5)\end{array}$ & 750 & 0 \\
\hline Cereal snacks & $\begin{array}{l}3 / 30 \\
(10)\end{array}$ & $289-467.8$ & 379.9 & $\begin{array}{c}45 \\
(83-38\end{array}$ & 500 & 0 \\
\hline Breakfast cornflakes & $\begin{array}{l}2 / 38 \\
(5.3)\end{array}$ & $110.8-279$ & 194.9 & $\begin{array}{c}47.4 \\
(57.6-10.3)\end{array}$ & 500 & 0 \\
\hline $\begin{array}{l}\text { Cereal products for infants and } \\
\text { young children }\end{array}$ & $0 / 93$ & - & - & $\begin{array}{c}20.2 \\
(20.2-0)\end{array}$ & 200 & 0 \\
\hline
\end{tabular}

MB (UB-LB): middle bound (upper bound- lower bound). UB - results below LOD were replaced by LOD and results below LOQ by LOQ. LB - results below LOD were replaced by 0 and results $M B$ (UB-LB): middle bound (upper bound-
below LOQ by LOD.

UE ML European Union maximum level

Studies by Ostry et al. [25] concerning the exposure of Czech consumers to mycotoxins, showed lower ZEA level for wheat flour $\left(0.76 \mu \mathrm{g} \mathrm{kg}^{-1}\right)$ and pasta $\left(0.57 \mu \mathrm{g} \mathrm{kg}^{-1}\right)$. According to Juan et al. [26], there was no this toxin in foods intended for infants and young children.

FUM were detected in 14 of 105 samples, i.e. 13.3\% (Tab. 4). The toxin was most often found in the samples of maize flour $25 \%$, maize grits $22.2 \%$, breakfast cornflakes $20 \%$, and maize snacks $10 \%$. The mean ZEA values ranged from 161.2 $\mu \mathrm{g} \mathrm{kg}^{-1}-202.4 \mu \mathrm{g} \mathrm{kg}$. . No FUM was found in cereal products intended for infants and young children.

The levels of FUM contamination determined by Kowalska et al. [27] in breakfast cornflakes in Poland, were lower and ranged from $28-132 \mu \mathrm{g} \mathrm{kg}^{-1}$, the average value $-75 \mu \mathrm{g} \mathrm{kg}^{-1}$. Sirot [23] also reported FUM contents within the range $1.7-8.5 \mu \mathrm{g} \mathrm{kg}^{-1}$. In turn, FUM levels detected in popcorn by Martins et al. [28] were higher, ranging from $89-1,170 \mu \mathrm{g} \mathrm{kg}^{-1}$ $\left(\mathrm{FB}_{1}\right)$ and $57-211 \mu \mathrm{g} \mathrm{kg}^{-1}\left(\mathrm{FB}_{2}\right)$ in $88.2 \%$ of the examined samples. Higher levels were also determined by CanoSancho et al. [29] in cornflakes: in 28 of 72 samples (39\%), the authors found the average level of FUM to be $78.9 \mu \mathrm{g} \mathrm{kg}^{-1}$. According to Galbenu et al. [30], FUM were present in 50\% of cornflake samples (2/4) at an average level of $30.5 \mu \mathrm{g} \mathrm{kg}^{-1}$. In turn, Martins et al. [28] showed FUM contamination in 7 of 30 samples of infant food (23.3\%) at the average level of $36.4 \mu \mathrm{g} \mathrm{kg}^{-1}$.

Analysis of variance between the type of mycotoxin and the type of product showed a statistically significant difference $(p<0.05)$ in the concentrations of DON, ZEA and FUM in the same products (breakfast cereals, maize flour, cereal products for infants and young children). Significant differences $(\mathrm{p}<0.05)$ were also observed between different products and mycotoxin concentrations (DON, ZEA and FUM).

Based on the results obtained, consumer risk assessment, resulting from the consumption of cereal products, was

Table 4. The content of FUM (sum of $B_{1}$ and $B_{2}$ ) in analyzed samples

\begin{tabular}{|c|c|c|c|c|c|c|}
\hline Product & $\begin{array}{l}\text { No. positive samples/ } \\
\text { examined samples (\%) }\end{array}$ & $\begin{array}{c}\text { Range } \\
\left(\min -\mathrm{max}, \mu \mathrm{g} \mathrm{kg}{ }^{-1}\right)\end{array}$ & $\begin{array}{l}\text { Mean of positive } \\
\text { samples }\left(\mu \mathrm{g} \mathrm{kg}^{-1}\right)\end{array}$ & $\begin{array}{c}\text { Mean MB } \\
(\mathrm{UB}-\mathrm{LB}, \mu \mathrm{g} \mathrm{kg})\end{array}$ & UE ML ( $\left.\mu \mathrm{g} \mathrm{kg}^{-1}\right)$ & $\begin{array}{c}\text { The number of } \\
\text { samples above MRL }\end{array}$ \\
\hline Breakfast cornflakes & $\begin{array}{l}7 / 35 \\
(20) \\
\end{array}$ & $151.0-201.8$ & 161.2 & $\begin{array}{c}62.1 \\
(94.3-32.2) \\
\end{array}$ & 800 & 0 \\
\hline Maize snacks & $\begin{array}{l}2 / 20 \\
(10.0)\end{array}$ & $151.2-188.3$ & 169.8 & $\begin{array}{c}67.5 \\
(84.5-17.0)\end{array}$ & 800 & 0 \\
\hline Maize grits & $\begin{array}{c}2 / 9 \\
(22.2)\end{array}$ & $152.6-155.1$ & 153.9 & $\begin{array}{c}52.5 \\
(83.4-30.8) \\
\end{array}$ & 1000 & 0 \\
\hline Maize flour & $\begin{array}{l}3 / 12 \\
(25)\end{array}$ & $160.8-216.4$ & 202.4 & $37.5(88.1-50.6)$ & 1000 & 0 \\
\hline $\begin{array}{l}\text { Cereal products for infants and } \\
\text { young children }\end{array}$ & $0 / 29$ & - & - & $\begin{array}{l}75.0 \\
(75-0\end{array}$ & 200 & 0 \\
\hline
\end{tabular}

MB (UB-LB): middle bound (upper bound- lower bound). UB - results below LOD were replaced by LOD and results below LOQ by LOQ. LB - results below LOD were replaced by 0 and results below LOQ by LOD.

UE ML European Union maximum level 
conducted with regard to the PMTDI or TDI value. Calculations were performed for the cereal products in which the investigated toxins were most frequently detected. For DON calculation these were: wheat flour, pasta, breakfast cornflakes, and bakery products; for FUM: maize flour, maize grit, and breakfast cornflakes; and for ZEA: corn flour. With regard to ZEA, the analysis was extended to cereal products with the highest consumption, i.e. bread and cornflakes. In all cases, exposure estimation was higher for the maximum mycotoxin levels than for the calculated $\mathrm{MB}$ value. Therefore, these values are taken into account in the following discussion.

The values of DON exposure due to consumption of cereal products, expressed as a percentage of permissible maximum total daily intake (\% PMTDI), fluctuated between $0.20-2.89 \%$ for wheat flour, $0.6-6.58 \%$ for pasta, $0.42-5.10 \%$, for breakfast cornflakes, and $0.40-5.80 \%$ for bread and bakery products (Tab. 5). The maximum value for wheat flour was obtained

Table 5. PMTDI or TDI values for deoxynivalenol, zearalenone, fumonisins in relation to individual age groups [\%]

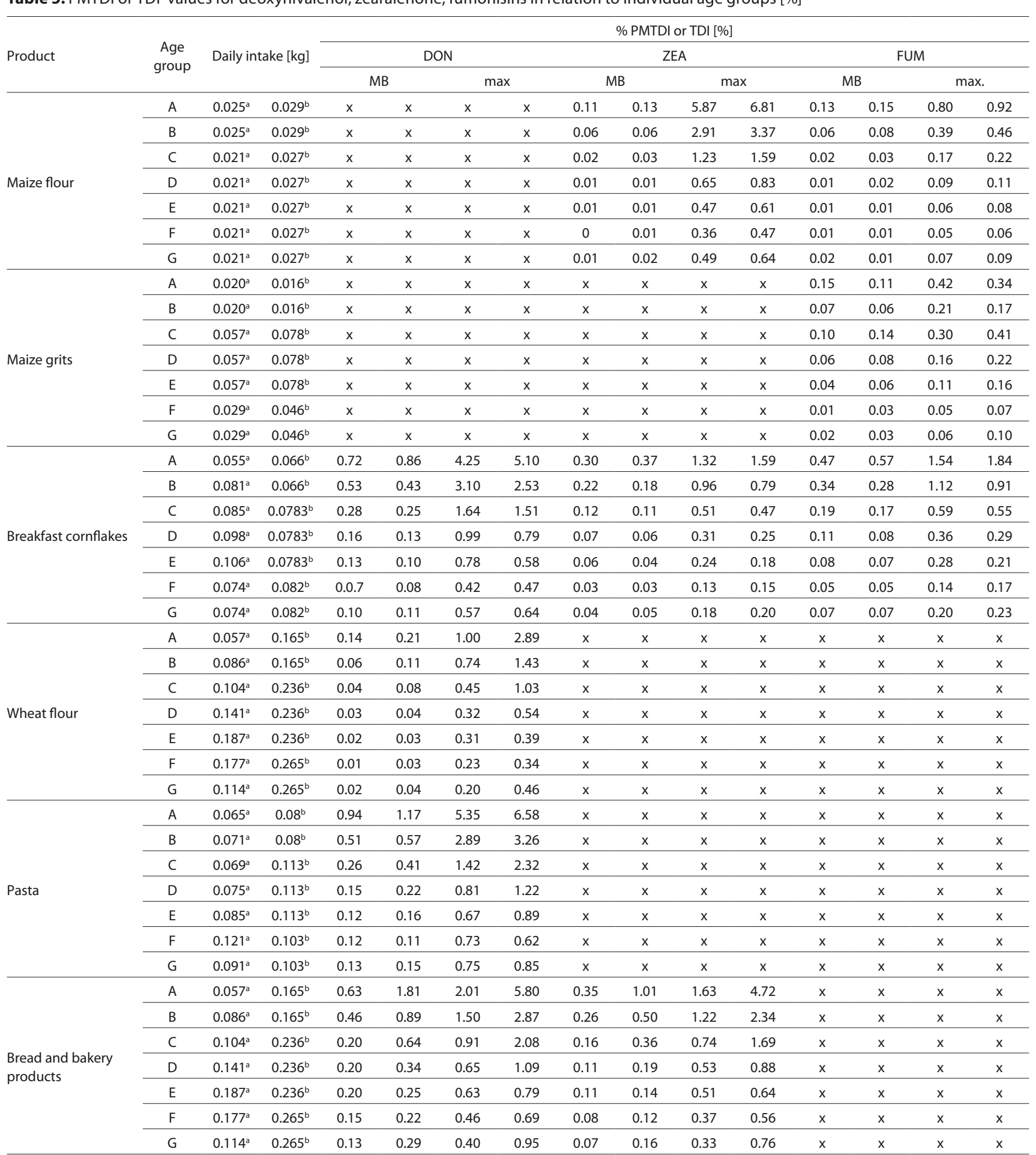

- data on food consumption were derived from the survey

$\mathrm{b}$ - food consumption data were derived from the EFSA Comprehensive European Food Consumption Database

$\mathrm{x}$ - not calculated 
for children 4-6-years-old, while the value determined for pasta was more than twice as high in this group. In the 3 oldest age groups (E, F, and G), the values determined did not exceed $1 \%$ for all products and for both consumption values.

According to Ostry et al. [25], the mean DON exposure doses were higher, ranging from $21-31 \%$ TDI (LB-UB) in children aged $4-6$, from $12 \%-29 \%$ TDI in men aged $18-50$, and from $8 \%-13 \%$ TDI in women aged $18-59$. Higher values were also determined by Stanciu et al., [31] for an adult population, where the estimated intake was less than the TD: $669 \mathrm{ng} \mathrm{kg}^{-1}$ b.w. per day (LB) and $690 \mathrm{ng} \mathrm{kg}^{-1}$ b.w. per day (UB). The values of DON intake reported by Pleadin et al. [32] did not exceed $10 \%$ of the TDI (LB). In turn, Rodríguez-Carrasco et al, [33] set the dietary DON intake from wheat-based products at the level of $43 \mathrm{ng} \mathrm{kg}^{-1}$ b.w. per day.

Also in the case the exposure to ZEA, the values obtained were below TDI (Tab. 5), and for the examined products ranged from $0.36 \%-6.81 \%$ for maize flour, $0.33-4.72 \%$ for bread and bakery products, and $0.13-1.59 \%$ for breakfast cornflakes The highest values for all the above products occurred in the group of children aged 4-6. On the other hand, dietary ZEA exposure estimates for wheat products intended for direct human consumption in the adult Romanian population, stated by Stanciu et al. [31], were lower - $25 \mathrm{ng} \mathrm{kg}^{-1}$ b.w. per day (UB). According to Pleadin et al. [32], ZEA intake from Croatian wheat and wheat flour did not exceed 7\% TDI (LB). In Portugal, Assunção et al, [34] calculated the mean total daily ZEA intake through the consumption of 3 groups of cereal products: breakfast cornflakes, biscuits and cereal products intended for infants. The value calculated for children under 3 years of age, was $0.89 \mathrm{ng} \mathrm{kg}^{-1}$ b.w. per day. The mean exposure of vegetarians to ZEA in France was estimated by Fleury et al. [35] at the level of $5.7 \mathrm{ng} \mathrm{kg}^{-1}$ b.w. per day at the LB, and $10.5 \mathrm{ng} \mathrm{kg}^{-1}$ b.w. per day at the UB. The main contributors to ZEA exposure were bread and dried bakery products $(23.2 \%-32 \%$, LB-UB) and pasta (from $12 \%-16.3 \%$ ).

Assessment of FUM exposure due to the consumption of cereal products is shown in Table 5 . The values obtained for maize flour and maize grit were within the ranges of 0.50 $0.92 \%$ and $0.05-0.42 \%$ PMTDI, respectively. The highest values were noted for cornflakes (0.14-1.84\% PMTDI) and, considering all products, the highest value was found for the group of children aged 4-6.

On the other hand, of all the examined mycotoxins, the exposure to FUM was the lowest. Higher average doses of FB exposure were reported by Do et al, [36] and Huong et al. [37]. In turn, a study by Kirimker et al. [38] on DON and FUM exposure of infants and young children in Turkey, showed that the mean FUM exposure dose was $0.068 \mu \mathrm{g} \mathrm{kg}-1$ b.w. per day for young children, i.e. 3.4\% PMTDI. The estimates in the current study are lower than the chronic exposure for the population of young children in EU Member States. In Europe, the average exposure to FUM was estimated in the range of $0.18-\mathrm{m} 1.65 \mu \mathrm{g} \mathrm{kg}^{-1}$ b.w. per day for young children [40].

\section{CONCLUSIONS}

The study proved the presence of DON, ZEA and FUM in commercially available cereal products from the Malopolska Voivodeship of Poland. Levels higher than those permissible for the examined cereal products were noted in only 2 cases.
FUMs were the most commonly found Fusarium mycotoxins, followed by DON and ZEA. The mean exposure doses of the assessed mycotoxins, resulting from the consumption of cereal products in the selected populations, were at low levels (reaching a maximum of 6.81\%) and did not exceed the TDI or PMTDI. Therefore, the observed average chronic exposure dose does not pose a health risk for consumers; however, consideration should be given to progressive climate change (warming) and its possible effect on the increased prevalence of Fusarium mycotoxins in cereal products. It is therefore necessary to continue monitoring for the occurrence of Fusarium mycotoxins in cereal products.

It should be noted that only a small number of papers are available on the contamination with DON, ZEA and FUM toxins of cereal products commercially available on the Polish market, whereas in the current study, a relatively large number of samples covering a broad assortment of the examined cereal products has been examined. Unfortunately, some limitations were also unavoidable, namely, the use of various analytical techniques by other researchers caused problems in comparing the results in the discussion. Moreover, despite the large number of examined samples, there was the small number of results (above LOQ), which caused difficulties in their interpretation.

\section{REFERENCES}

1. Wang L, Liao Y, Peng Z, et al. Food raw materials and food production occurrences of deoxynivalenol in different regions. Trends Food Sci Technol. 2019; 83: 41-52. https://doi.org/10.1016/j.tifs.2018.11.003

2. Postupolski J, Starski A, Ledzion E, et al. Exposure assessment of infants and young children on selected Fusarium toxins. Ann National Instit Hygiene. 2019; 70: 5-14. https://doi.org/10.32394/rpzh.2019.0050

3. Pleadin J, Vahčić N, Perši N, et al. Fusarium mycotoxins occurrence in cereals harvested from Croatian fields. Food Control. 2013; 32: 49-54. https://doi.org/10.1016/j.foodcont.2012.12.002

4. Stanciu O, Juan C, Berrada H, et al. Study on trichothecene and zearalenone presence in romanian wheat relative to weather conditions. Toxins. 2019; 11(3): 163-180. https://doi.org/10.3390/toxins11030163

5. Pokrzywa P, Cieslik E, Surma M. Effect of storage conditions on the formation of type A and B trichothecenes in cereal products. Ann Agric Environ Med. 2019; 26: 260-265. https://doi.org/10.26444/aaem/103398

6. Chen C, Turna NS, Wu F. Risk assessment of dietary deoxynivalenol exposure in wheat products worldwide: Are new codex DON guidelines adequately protective? Trends Food Sci Technol. 2019; 89: 11-25. https:// doi.org/10.1016/j.tifs.2019.05.002

7. Simsek S, Burgess K, Whitney KL, et al. Analysis of Deoxynivalenol and Deoxynivalenol-3-glucoside in wheat. Food Control. 2012; 26: 287-292. https://doi.org/10.1016/j.foodcont.2012.01.056

8. Latorre A, Dagnac T, Lorenzo BF, et al. Occurrence and stability of masked fumonisins in corn silage samples. Food Chem. 2015; 189: 38-44. https://doi.org/ 10.1016/j.foodchem.2014.10.156

9. Reisinger NN, Dohnal I, Nagl V, et al. Fumonisin $B_{1}\left(F_{1}\right)$ induces lamellar separation and alters sphingolipid metabolism of in vitro cultured hoof explants. Toxins. 2016; 8(4): 89. https://doi.org/10.3390/ toxins 8040089

10. Kowalska K, Habrowska-Górczynska DE, Piastowska-Ciesielska AW. Zearalenone as an endocrine disruptor in humans. Environ Toxicol Pharmacol. 2016; 48: 141-149. https://doi.org/10.1016/j.etap.2016.10.015

11. Commission Regulation (EC) No 1881/2006 of 19 December 2006 setting maximum levels for certain contaminants in foodstuffs. L.2006; 364: 5-24.

12. EFSA (European Food Safety Authority) Evaluation of the increase of risk for public health related to a possible temporary derogation from the maximum level of deoxynivalenol, zearalenone and fumonisins for maize and maize products, EFSA J. 2014; 12(5): 3699. https://doi. org/10.2903/j.efsa.2014.3699

13. Commission Regulation (EC) No 401/2006 of 23 February 2006 laying down the methods of sampling and analysis for the official control of the levels of mycotoxins in foodstuffs. L. 2006; 70: 12-34, 2006. 
14. EFSA (European Food Safety Authority), 2010. Management of leftcensored data in dietary exposure assessment of chemical substances. EFSA J. 2010; 8: 1557. https://doi.org/10.2903/j.efsa.2010.1557

15. Vidal A, Morales H, Sanchis V, et al. Stability of DON and OTA during the breadmaking process and determination of process and performance criteria. Food Control. 2014; 40: 234-242. https://doi. org/10.1016/j.foodcont.2013.11.044

16. Jarosz M, Rychlik E, Stoś K, et al. Nutritional norms for the Polish population and their application. https://www.pzh.gov.pl/wp-content/ uploads/2020/12/Normy_zywienia_2020web-1.pdf (access: 2021.06.20)

17. Dobosz B, Król K, Lar K, et al. Presence of mycotoxins in cereal preparations on the market in Silesia Province from 2013 to 2015. Environ Med. 2017; 20(1): 34-40. https://doi.org/10.19243/2017104

18. Mruczyk K, Mizgier M, Wójciak RW, et al. Comparison of deoxynivalenol and zearaleone concentration in conventional and organic cereal products in western Poland. Ann Agric Environ Med. 2021; 28(1): 44-48. https://doi.org/10.26444/aaem/116417

19. Darsanaki RK, Issazadeh K, Aliabadi MA, et al. Occurrence of Deoxynivalenol (DON) in wheat flours in Guilan Province, northern Iran. Ann Agric Environ Med. 2015; 22(1): 35-37. https://doi. org/10.5604/12321966.1141366

20. Malachova A, Dzuman Z, Veprikova Z, et al. Deoxynivalenol, deoxynivalenol-3-glucoside, and enniatins: The major mycotoxins found in cereal-based products on the Czech market. J Agric Food Chem. 2011; 59: 12990-12997. https://doi.org/10.1021/jf203391x

21. González-Osnaya L, Cortés C, Soriano J, et al. Occurrence of deoxynivalenol and T-2 toxin in bread and pasta commercialised in Spain. Food Chemistry. 2011; 124: 156-161. https://doi.org/10.1016/j. foodchem.2010.06.002

22. Golge O, Kabak B. Occurrence of deoxynivalenol and zearalenone in cereals and cereal products from Turkey. Food Control. 2020; 110: 106982, https://doi.org/10.1016/j.foodcont.2019.106982

23. Sirot V, Fremy JM, Leblanc JC. Dietary exposure to mycotoxins and health risk assessment in the second French total diet study. Food Chem Toxicol. 2012; 52: 1-11. https://doi.org/10.1016/j.fct.2012.10.036

24. Cano-Sancho G, Marin S, Ramos AJ, et al. Occurrence of zearalenone, an oestrogenic mycotoxin, in Catalonia (Spain) and exposure assessment. Food Chem Toxicol. 2012; 50: 835-839. https://doi.org/10.1016/j. fct.2011.11.049

25. Ostry V, Dofkova M, Blahova J, et al. Dietary exposure assessment of sum deoxynivalenol forms, sum T-2/HT-2 toxins and zearalenone from cereal-based foods and beer. Food Chem Toxicol. 2020; 139: 111280. doi: $10.1016 /$ j.fct.2020.111280

26. Juan C, Raiola A, Mañes J, et al. Presence of mycotoxin in commercial infant formulas and baby foods from Italian market. Food Control. 2014;39:227-236. https://doi.org /10.1016/j.foodcont.2013.10.036

27. Kowalska A, Hajok I, Piekut A. Assessment of the contamination level by Fumonisins $\mathrm{B} 1$ and $\mathrm{B} 2$ of the corn food products available on Polish consumer market. Pol J Environ Stud. 2017; 26(6): 2595-2601. https:// doi.org/10.15244/pjoes/70386

28. Martins FA, Ferreira FMD, Ferreira FD, et al. Daily intake estimates of fumonisins in corn-based food products in the population of Parana, Brazil. Food Control. 2012; 26: 614-618. https://doi.org/10.1016/j. foodcont.2012.02.019

29. Cano-Sancho G, Ramos AJ, Marin S, et al. Occurrence of fumonisins in Catalonia (Spain) and an exposure assessment of specific population groups. Food Addit. Contam Part A. 2012; 29: 799-808. https://doi.or g/10.1080/19440049.2011.644813

30. Galbenu P, Damiescu L, Trif A. Fumonisin occurrence in cereal and cereal-based foodstuffs marketed in Timis County. Res J Agric Sci. 2011; 43(1): 50.

31. Stanciu O, Juan C, Miere D, et al. First study on trichothecene and zearalenone exposure of the Romanian population through wheatbased products consumption. Food Chem Toxicol. 2018; 121:336-342. https:// doi.org/10.1016/j.fct.2018.09.014

32. Pleadin J, Staver MM, Markov K, et al. Mycotoxins in organic and conventional cereals and cereal products grown and marketed in Croatia. Mycotoxin Res. 2017; 33: 219-227. https://doi.org/10.1007/ s12550-017-0280-3

33. Rodríguez-Carrasco Y, Moltó JC, Berrada H, et al. A survey of trichothecenes, zearalenone and patulin in milled grain-based products using GC-MS/MS. Food Chem. 2014; 146: 212-219. https:// doi.org/10.1016/j.foodchem.2013.09.053

34. Assunção R, Martins C, Vasco E, et al. Portuguese children dietary exposure to multiple mycotoxins - an overview of risk assessment under MYCOMIX project. Food Chem Toxicol. 2018; 118: 399-408. https://doi.org/10.1016/j.fct.2018.05.040

35. Fleury S, Rivière G, Allès B, et al. Exposure to contaminants and nutritional intakes in a French vegetarian population. Food Chem Toxicol. 2017; 109: 218-229. https://doi.org/10.1016/j.fct.2017.07.048

36. Do TH, Tran SC, Le CD, et al. Dietary exposure and health risk characterization of aflatoxin $\mathrm{B} 1$, ochratoxin $\mathrm{A}$, fumonisin $\mathrm{B} 1$, and zearalenone in food from different provinces in Northern Vietnam. Food Control. 2020; 112: 107-108. https://doi.org/10.1016/j. foodcont.2020.107108

37. Huong BTM, Brimer L, Dalsgaard A. Dietary exposure to aflatoxin B1, ochratoxin A and fuminisins of adults in Lao Cai province, Vietnam: A total dietary study approach. Food Chem Toxicol. 2016; 98: 127-133. https://doi.org/10.1016/j.fct.2016.10.012

38. Kirimker SE, Turksoy S, Kabak B. Assessment of dietary exposure to deoxynivalenol and fumonisin in the population of infants and toddlers in Turkey. Food Chem Toxicol. 2020; 140: 111304. https://doi. org/10.1016/j.fct.2020.111304

39. EFSA (European Food Safety Authority), 2014. Scientific opinion on the risks for human and animal health related to the presence of modified forms of certain mycotoxins in food and feed. EFSA J. 2014; 12: 3916. https://doi.org/10.2903/j.efsa.2014.3916. 